\title{
Kebudayaan Towani Tolotang Kabupaten Sidenreng Rappang
}

\author{
Muh. Ardiansyah \\ Departement of Antropology Education, Faculty of Social Science and Law, \\ Universitas Negeri Makassar, Indonesia \\ E-mail: ancacu103@gmail.com
}

\begin{abstract}
This paper aims to describe the scope of Towani Tolotang culture by explaining the history of the Towani Tolotang people, the spread of Towani Tolotang in Sidenreng Rappang Regency, how Towani Tolotang religiousization in Indonesia, belief systems and social dynamics of the Towani Tolotang people. The method used in this research is descriptive qualitative method, qualitative method is used to describe how the scope of Towani Tolotang culture is located in Sidenrang Rappang Regency. The end of this study will show the cultural implications of the Towani Tolotang community on the local belief system of the community.
\end{abstract}

Keywords: kebudayaan, Towani, Tolotang.

\section{References}

Ahmadin, A. (2013). Metode penelitian sosial.

Sugiarti. 2020. Dinamika Komunitas Hindu Towani Tolirang di Sulawesi Selatan. Jurnal Agama dan Budaya. Vol.4, No.1 Hal.23-32.

Syukur, Nur Ahsan. 2015. Kepercayaan Tolotang dalam Perpektif Masyarakat Bugis Sidrap. Jurnal Rihlah. Vol. III No.1. Makassar: UIN Alauddin Makassar.

J, Hasse. 2020. Kebijakan Negara Terhadap Agama Lokal’Towani Tolotang” di Kabupaten Siderap, Sulawesi Selatan..

J, Hasse. Risakotta, Bernard Adeney. Bagir, Zainal Abidin. Diskriminasi Negara Terhadap Agama di Indonesia : Studi atas Persoalan Posisi Hukum Towani Tolotang Pasca Pengakuan Agama Resmi. Jurnal Kawistara. Vol.1, No.2. Hal 103-212.

Rusli, Muh. 2012. Kearifan Lokal Masyakat Towani Tolotang di Kabupaten Sidenreng Rappang. Jurnal Al-Ulum. Vol.12, No 2. Hal 447-496. Gorontalo: Institut Agama Islam Negeri Sultan Amai

Kurniawan, Rahmat. Bahri. Asmunandar. 2018. Persebaran To Lotang setelah Aksi DI/TII di Kabupaten Sidenreng Rappang. Jurnal Pemikiran, Pendidikan dan Penelitian Kesejarahan. Vol. 7, No.1, Hal 1-12. Makassar : Univesitas Negeri Makassar 
Wihdaniah. Agusntang, Andi. Adam, Arlin. Pernikahan Tolotang di Kelurahan Amparita Kecamatan Tellu Limpoe Kabupaten Sidenreng Rappang. Jurnal Phinisi Integration Review. Vol.3, No.2. Hal 165-172. Makassar: Univesitas Negeri Makassar

Mattulada. 1982. Manusia dan Kebudayaan Bugis-Makassar. Dalam berita Anropologi, Tahun XI, Nomor 38 JuliSeptember, 1980. Jakarta : Univesitas Indonesia.

Qoyim, I., 2014. Agama dan Pandangan Hidup Masyakat Towani Tolotang. Dalam Ibunu Qayim(ed.). Religi Lokal dan Pandangan Hidup : Kajian tentang masyarakat Penganut Religi Tolotang dan Patuntung, Sipelebegu, (Permalin), Saminisme, dan Agama Jawa Sunda. Jakarta: Lembaga Ilmu Pengetahuan Indonesia Pusat Penelitian Kemasyarakatan dan Kebudayaan (PMB-LIPI).

Bahri, S. dkk. (2012). Kepercayaan dan Upacara Tradisional Komunitas Adat di Sulawesi Selatan : Kajian Komunitas Adat Toani Tolotang dan Komunitas Kajang. De La Macca (Anggota Ikapi Sulawesi Selatan).

Iskandar, Jamaluddin. 2019. Kepercayaan Komunitas Towani Tolotang. Al-Tadabbur: Kajian Sosial, Peradaban dan Agama. Vol. 1, No. 1

Hajji. 2014. Agama sebagai Konsep Sosial Towani Tolotang di Kabupaten Sidrap. Tesis. Makassar: Program Pascasarjana Univesitas Negeri Makassar.

Wa'Jappi. (2020, Maret 13). Kondisi Ekonomi Masyarakat To Lotang. (R. Kurniawan, Interviewer)

Wa'Launga. (2009). Kearifan Lokal Masyarakat Towani Tolotang di Kabupaten Sidenreng Rappang. Jurnal Al, Vol.12, No. 2. Hal. 7. 